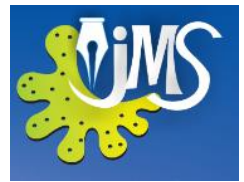

\title{
Roads to Transdisciplinarity: Developing a Sustainable Management Approach
}

\author{
${ }^{1}$ Fritz Schiemer \\ ${ }^{1}$ Department of Limnology and Bio-Oceanography, Faculty of Life Sciences, University Vienna, \\ Vienna
}

\begin{abstract}
Exploring strategies for sustainable management requires a scientific and problem-oriented approach combining environmental and socio-economic aspects in view of the manifold issues and often conflicting stakeholder interests. It calls for more interdisciplinarity in science, translational research, and transdisciplinarity in form of science-practitioners interactions. By tradition, scientists are usually confined to specialized niches of knowledge and do not easily embark on interdisciplinary endeavors, which demand new research approaches. Translational research - defining ways to communicate with practitioners and introducing research findings into political decisions - demands new and diverse formats of education, training and networking.
\end{abstract}

I use examples of personal engagement in water issues over the last 30 years to outline the challenges of applied research and science-policy interactions. The first two examples refer to a long-term engagement in resource management of SE-Asian reservoirs and lakes. Following an early ecosystem-oriented study on the Parakrama Samudra reservoir in Sri Lanka (1979-1982), a multidisciplinary EU-program was launched. The international project, carried out by a consortium of Asian and European scientists, provided a large amount of factual information (Schiemer et al. 2008) and a wealth of experience regarding the challenges to transfer scientific knowledge into realworld politics.

The second set of experience refers to the management of the riverine landscape which a wide variety of ecological services, e.g. flood retention, drinking water supply, conservation, hydropower production and navigation. These represent partially conflicting interests of different political power. Human impacts over the past 150 years through river regulation, damming and pollution have reduced some of the service capacities and call for rehabilitation measures. In the early 1980-ties I became engaged in a major public discussion over a hydropower project of the Danube in Austria. As a result of the critical position taken by scientists, we were invited by the government to take part in a commission of practitioners, planners and scientists to develop long-term management concepts.

Corresponding author: Fritz Schiemer, Email: friedrich.schiemer@univie.ac.at 
The panel was requested to find science-based compromises for conflicting stakeholder interests. This engagement forced scientists of various disciplines - ecologists, hydrologists, and geomorphologiststo develop a common understanding of the vulnerability of river-floodplain systems to human interventions. Over the past thirty years, scientists played a significant role in this discussion process, defining environmental targets and developing benchmarking and assessment criteria for management options. This involvement was also a school of learning regarding interaction with stakeholders and decision makers.

KEYWORDS: Aquatic resource management, eco-hydrology, eco-sociology, translational science, stakeholder controversies, co-management, fisheries, trophic state, river restoration 


\section{THE CHALLENGES FOR SCIENCE}

The paper is based on a key-note address at a conference on multidisciplinary approaches from $11^{\text {th }}-12^{\text {th }}$ September 2015 in Colombo, Sri Lanka. The title reflects the long and tedious paths necessary to achieve and implement integrated management strategies. There are many steps to be taken and many hurdles to overcome. It is now generally recognized that science has to play an important and manifold role. Within academia there is growing awareness that pure research is insufficient and that a transdisciplinary approach by connecting science to real world decisions is required.

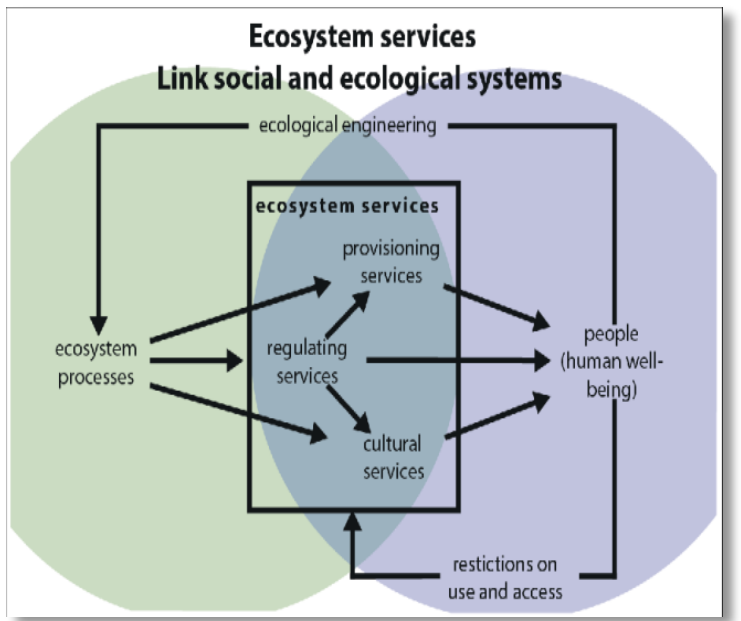

Figure 1. Ecological services depend on ecosystem functions, which can be strongly influenced by human interactions. The scheme illustrates the complex interactions, which have to be considered (from Bennett, Peterson \& Gordon, 2009).

Sustainable resource management has to approach a harmonization between environmental, social and economical requirements without detrimental effects to the resource itself. A primary aspect is the understanding of ecosystem functions which guarantee the ecological services (Daily et al. 1997) in form of provisional services like clean water or fisheries, regulating services like flood control and self purification processes, and cultural services like landscape aesthetics (tourism) and recreation. They are dependent on the structure and functioning of the ecological system. The manifold interactions and human interferences e.g. through engineering, pollution, carbon dioxide output, nutrient accumulation etc. can lead to degradations and deficiencies. An understanding of the environmental system providing the ecological services requires a systemic approach (Figure 1).

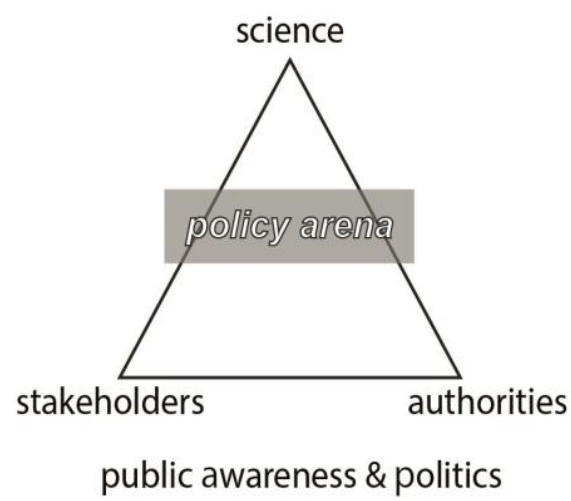

Figure 2. In formulating management plans three parties are involved - authorities stakeholders and scientists. The policy arena addresses the required dialogue between them. Decisions are influenced by public awareness and political will.

In pursuing sustainable management issues, three parties play a significant role (Figure 2): firstly responsible authorities, secondly stakeholders of various interests, political influence and power, and thirdly scientists of different disciplines interacting to understand the environmental and socioeconomic system. The acceptance of management plans depends strongly on public opinion and the political will. The policy arena, the interaction between scientists and practitioners, requires a transdisciplinary approach.

A global and burning issue, which requires a sound scientific basis, concerns an integrated water resource management (Bogardi et al. 2012, Korsgaard \& Schou, 2010). I will exemplify the challenges on the basis of personal experiences from engagements over the past 35 years on such 
issues, both in the tropics and the temperate zone. The chronology of these experiences presents a long process of recognizing the importance of interdisciplinarity and transdisciplinarity.

The following comments address

- the multiple challenges for science,

- the necessity to develop a functional understanding of resource systems including human use and impacts,

- the necessity for hypothesis - based research programs for analyzing the effects of management measures,

- the required interdisciplinary and translational research,

- the required interactio of scientists, authorities and stakeholders in planning and decision making, and

- the required improvment of legislative tools in order to achieve these goals.

\section{EXAMPLES}

\subsection{The Parakrama Samudra Limnology Project}

My long-term involvement in aquatic resource management in SE-Asian reservoirs and lakes started with the "Parakramas Samudra Project" in Sri Lanka, with field research from 1979 to 1982. The scientific program was aimed at gaining a better background on aquatic ecology in tropical countries, in order to strengthen our teaching in a postgraduate training program in limnology for students from developing countries. This course has been running since 1975 with an initial syllabus based on temperate zone limnology.

We recognized the need for capacity building through continued cooperation. Therefore we planned a limnological project at the Parakrama Samudra reservoir. A. Gunatilaka, a participant of one of the first courses in Austria, established contacts with colleagues from the Kelaniya University (H.H. Costa and S. De Silva), the National Science Foundation, the Ceylon Institute of Scientific and Industrial Research (C.I.S.I.R) and the Ministry of Fisheries in Sri Lanka. The project was conceived as a cooperative effort between European and Sri Lankan scientists (Figure 3).

The reservoirs in SE Asia are generally more intensively utilized than water-bodies in the temperate zone, with a broad range of uses, e.g. for irrigation, drinking water abstraction, fisheries amongst others. The need for sustainable management is more pressing and complex. The research scope followed the ecosystem concept as applied in the "International Biological Program" (1968-1973) (Le Cren \& Lowe-McConnell, 1975). We focused on ecosystem properties that are especially relevant for fisheries. Our working plan (Figure 4) was based on a scheme of major ecosysteminterrelationships (Schiemer, 1981).

Factors of overruling importance are the meteorological events of the monsoonal cycle and the use of water for irrigation, which cause a series of "macroevents". A study of the reactions of the ecosystem towards the imposed boundary conditions necessitates a multidisciplinary approach including hydro-meteorology, nutrient chemistry and biology. By drawing information from the various disciplines we were able to define the important ecosystem interlinks. A main focus of the Parakrama Samudra program was the control of the trophic state and the water quality of the reservoir and the internal nutrient recycling processes (Gunatilaka, 1983). A further focus was a detailed analysis of the structure of the fish community as well as the limnological role and fisheries-potential of the high densities of small sized species (see below). 

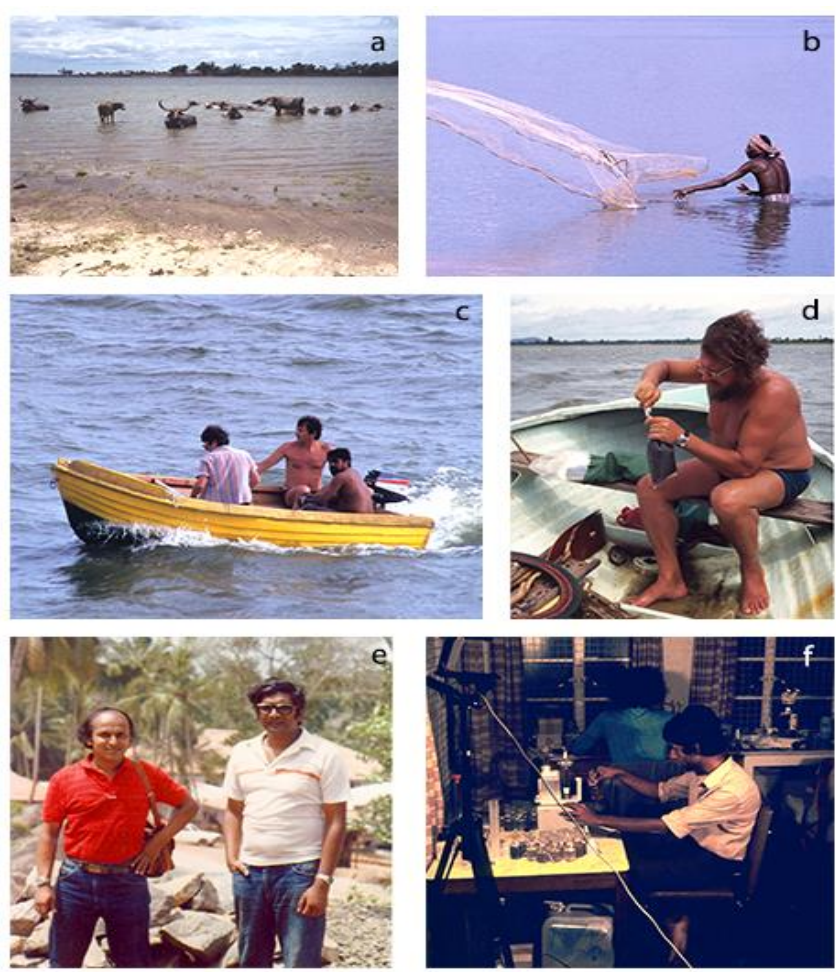

a) The shallow northern basin of the reservoir,

b) Cast net fishing in the inshore zone,

c) Sampling the reservoir: the late Nan Duncan, Fritz Schiemer and Ivan Silva,

d) Gernot Bretschko collecting sediment,

e) Amara Gunatilaka and Sena de Silva at the Polunnaruwa Fisheries Station,

f) Sri Lankan students analyzing water samples in our field lab in the Polunnaruwa Rest house.

Figure 3. A photo gallery of the Parakrama Samudra project, 1979-1982.

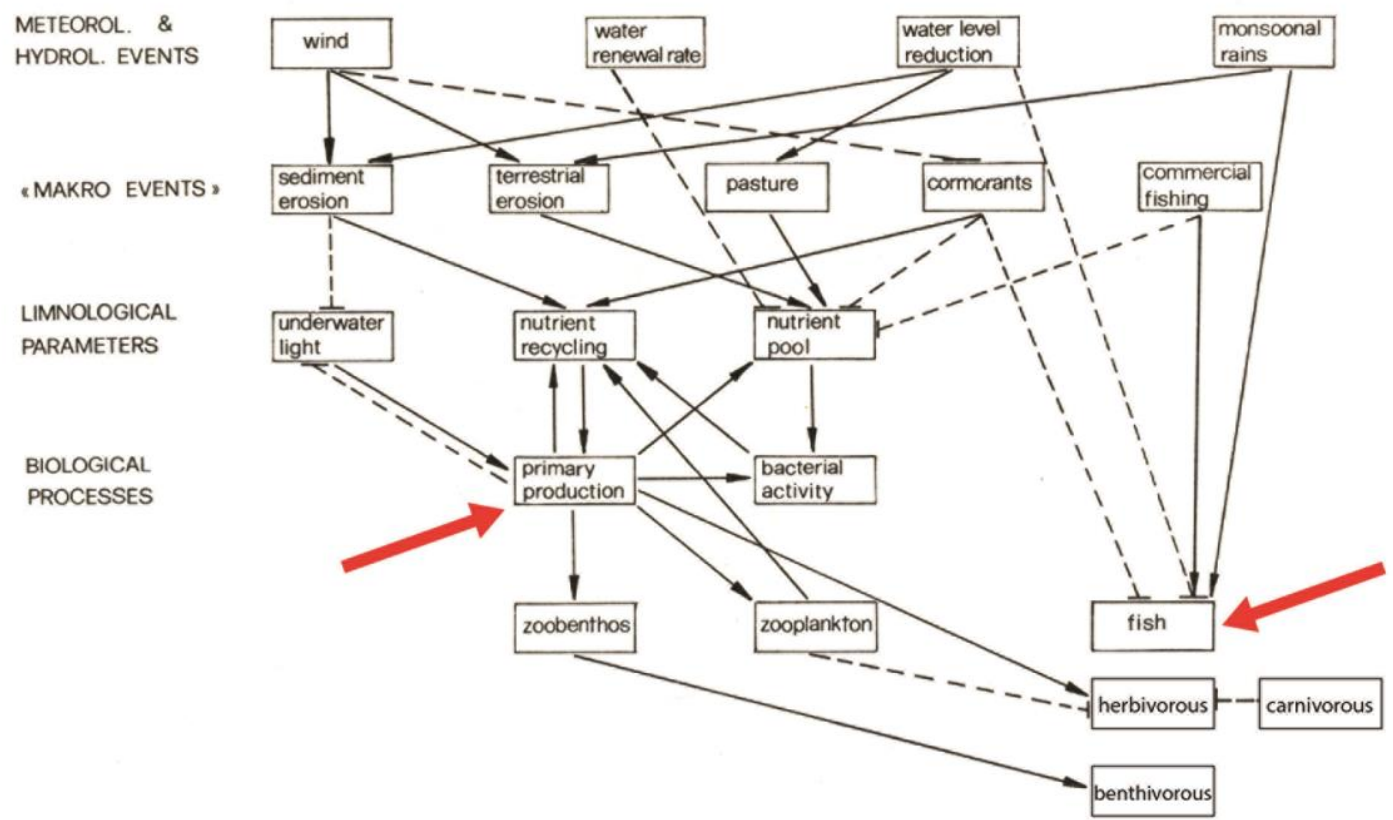

Figure 4. The working concept of the Parakrama Samudra project was based on main interrelationships of the reservoir ecosystem.

Solid line = stimulating effects, dashed line = depressing effects (after Schiemer, 1981).

The red arrows indicate the two aspects, which received particular attention: a) the trophic state and productivity of the open water communities and b) the ecologv of the fish fauna. 
These findings opened up avenues for a stronger science-oriented approach regarding the utilization of the reservoirs, and stimulated more intensive inland fisheries (De Silva \& Sirisena 1987). Some of the graduates involved in the program gained key positions in aquatic and fisheries science and the relevant administration in the country.

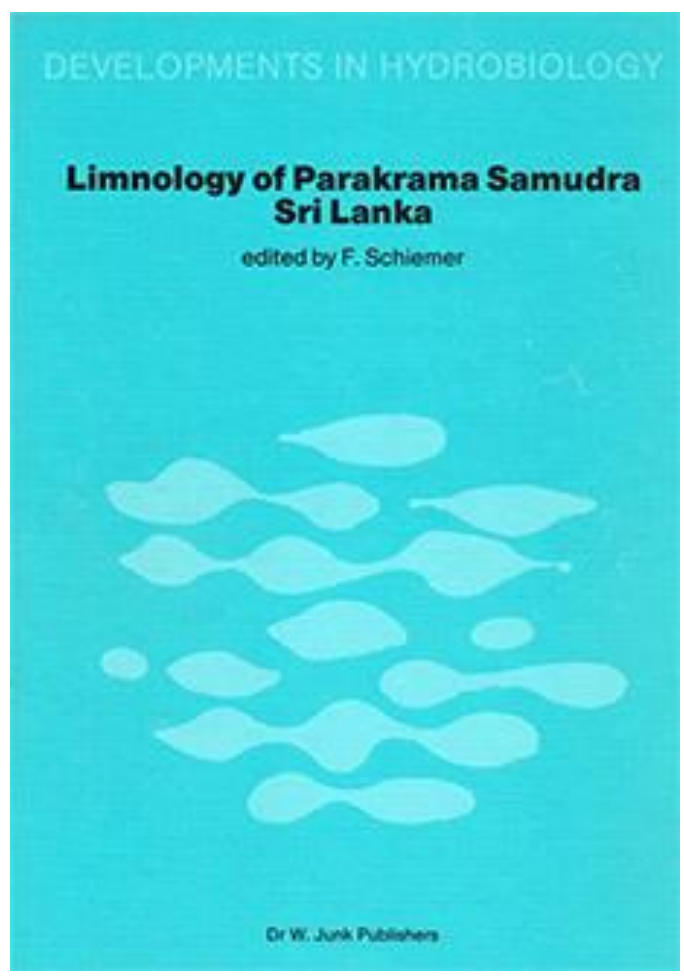

Figure 5. Cover of the book on the results of the Parakrama Samudra project in the series "Developments of Hydrobiology" (Schiemer, 1983, ed.).

The Parakrama Samudra project was successful as an ecosystem-oriented study, which demonstrated the value and the challenges of multidisciplinary research. Results were published in a book (Schiemer 1983) (Figure 5). In summarizing papers we proposed recommendations for fisheries (Schiemer \& Duncan 1983) and landscape management (Duncan et al. 1993). However, the program was not sufficient (and apparently the time not right) for an overall concept for sustainable management.

\subsection{The EU-funded "Fishstrat" program}

Based on these experiences, in the mid 1990's we conceived a more comprehensive study on sustainable aquatic resource management of SE-Asian water bodies. The EU-funded Fishstrat program, which ran officially from 1998-2003, had a long-winded title: "Strategies for partitioning the productivity of Asian reservoirs and lakes between capture fisheries and aquaculture for social benefit and local market without negative environmental impacts" (Amarasinghe et al. 2001). We followed a praxis-oriented approach with the main goal of analyzing the potential of fisheries and aquaculture in order to increase the protein supply for the local population. The program included a detailed socio-economic analysis of the riparian population, their economic activities and resource uses (Figure 6).

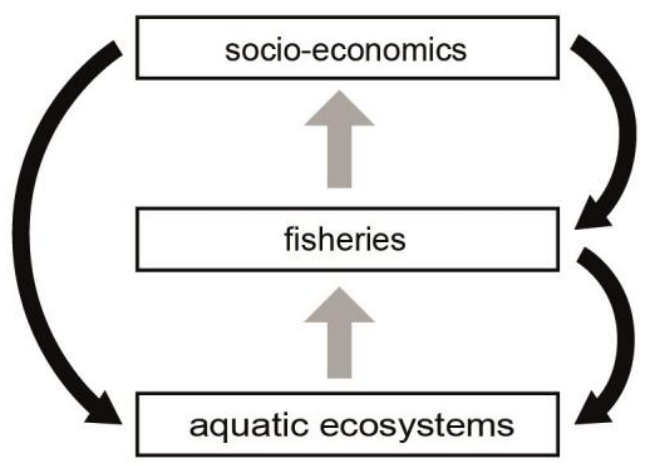

Figure 6. Major research fields of the "Fishstrat" program (after Schiemer et al., 2001).

The Fishstrat project involved research teams from Sri Lanka, Thailand, the Phillippines, UK, Austria, France, the Netherlands and the Czech Republic. It was organized in three phases. In phase 1 - the preparatory phase $-\mathrm{a}$ very significant meeting was held at the "Institute of Fundamental Studies" at Kandy, Sri Lanka, where all the research teams from the different countries met and formulated the research plan and methodologies to be applied. Phase 2, the practical fieldwork, was organized in four work packages - limnology, fisheries, aquaculture and socio-economics during which the teams worked largely 
independently from each other. In phase 3 , the data sets of the individual disciplines were analyzed and attempts were made in several meetings to integrate the results and formulate recommendations for management. Finally a "user meeting" was held in Bangkok, in which results and recommendations were discussed with practitioners.

\section{a) Bottom up approach}

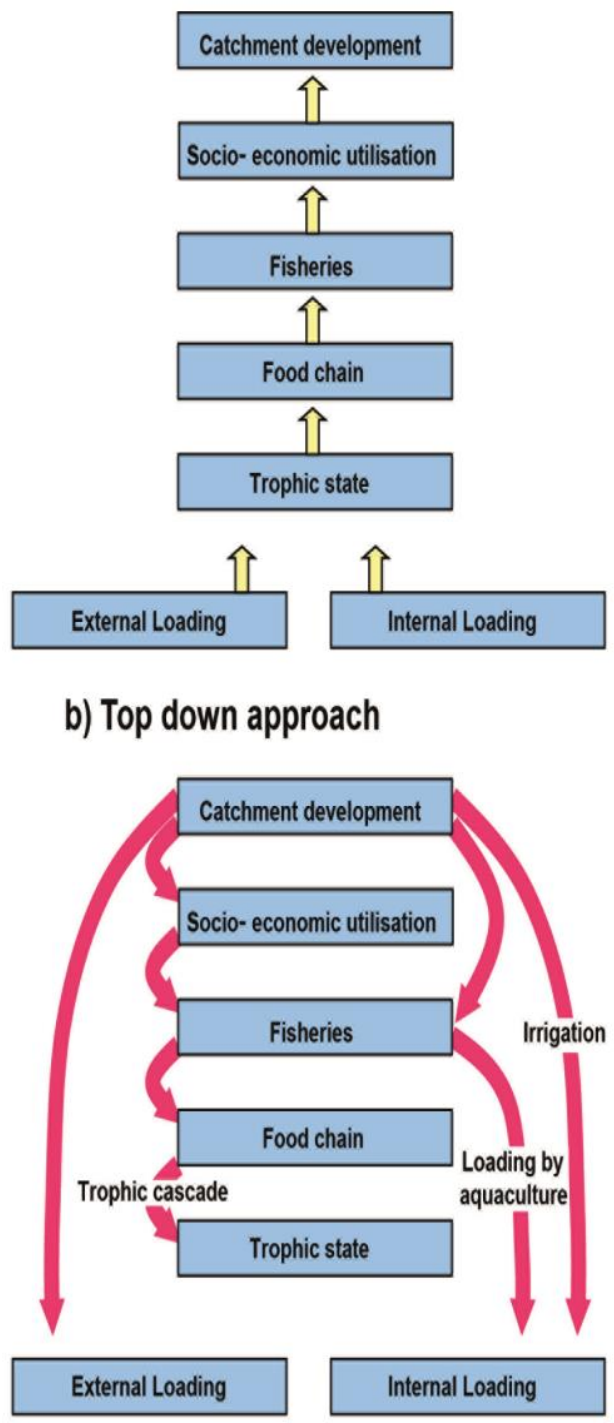

Figure 7. Key issues analyzed in the Fishstrat program with bottom-up (a), and top-down interrelationships (b) (acc. to Schiemer \& Simon, 2008).
The principal challenge was to understand the systems interactions and interlinks between limnology, fisheries and socioeconomics both in a bottom-up and a topdown form.

"Bottom-up" means an assessment of the loading with nutrients and hazardous substances from the catchment, its effects on the primary productivity and water quality of the reservoir and, in turn, on the fisheries and the livelihood conditions for the rural population (Fig. 7a). "Top-down" addresses the multiple effects via the hydrological management for irrigation as well as the controlling effects of biological interactions within the aquatic system (Fig. $7 b)$.

The intersection between the catchment and the reservoir or lake ecosytem is mainly controlled by hydrology. Phytoplankton biomass and primary productivity of the reservoir are to a large extent dependent on the external loading, especially of phosphorus, from the catchment. On the other hand, clear evidence from our research indicates that hydrological engineering of the reservoirs exerts a profound influence on the trophic state (Silva \& Schiemer 2008).

Algal biomass is reduced by high throughflow and short retention times, i.e. during periods of increased water demand for irrigation. Draw-down, on the other hand, enhances the trophic state by increased recycling of nutrients from the sediments due to wind induced currents. Moreover the activity of dense fish populations, including tilapias, contribute to the internal nutrient loading and the danger of hyper-eutrophication. These processes have to be addressed by management. (Duncan \& Schiemer 1988, Schiemer \& Duncan 1988, Schiemer 1996, Schiemer 2008). 


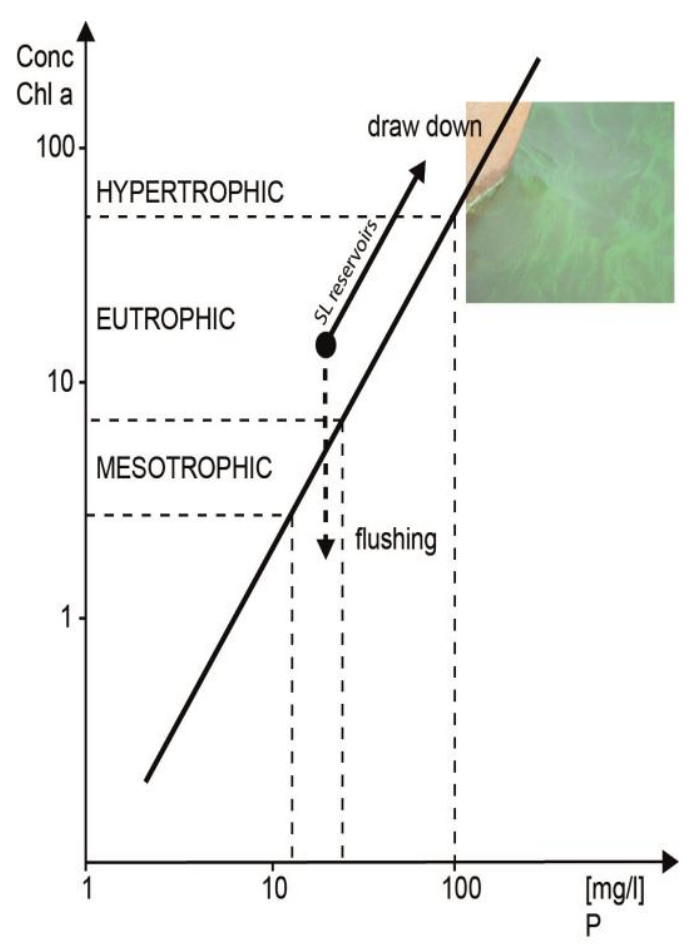

Figure 8. Relationship between total phosphorus $(\mathrm{mg} / \mathrm{m} 3)$ and the concentration of chlorophyll a $(\mathrm{mg} / \mathrm{m} 3)$ as a measure of phytoplankton concentration. The full line represents the regression line calculated for temperate zone water bodies. The data for Sri Lankan reservoirs lie higher but are strongly influenced by hydrology. The insert shows blue-green algae blooms as a sign of hypereutrophication and low water quality (based on data from Schiemer, 2008).

Figure 8 illustrates the relationship between the phosphorus content and phytoplankton biomass, expressed as concentrations of chlorophyll a. For lakes and reservoirs of the temperate zone there exists a wellestablished relationship (thick line). The comparison shows that the values found for Sri Lankan reservoirs are high and generally lie above the temperate zone regression line.

Phytoplankton concentrations are strongly influenced by the hydrological management of water bodies. They are enhanced at high water retention due to internal loading processes but strongly decrease during times of reservoir flushing. The findings clearly demonstrate that the trophic situation is critical and very sensitive to management and that care has to be taken to control both the external and internal nutrient loading. Research carried out on fish adressed the population dynamics of major exploited and unexploited species. We discovered high densities and a high productivity of small sized fish species in the shallow lowland reservoirs, representing unexploited resources and a high potential for fisheries development (Figure 9).

The possibilities for additional cage culturing of fish, e.g. tilapias, in the irrigation reservoirs were carefully evaluated. We came to the conclusion that the potential is low, primarily due to the danger of hypertrophication through fish feeding. Periodic phases of deoxygenation and fish kills in the inshore zones in lakes with intensive cage culturing, e.g. in the Philippines, gave clear warning signals. A further obstacle for cage culturing in irrigation reservoirs are operational difficulties due to the large seasonal water level fluctuations.

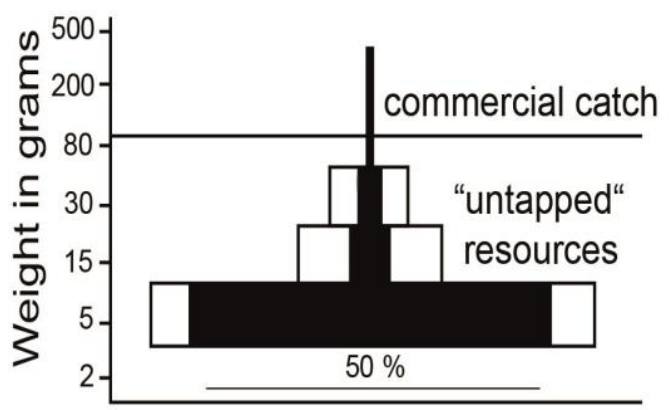

Figure 9. Biomass pyramid of the fish community in Sri Lankan reservoirs. The different weight classes of fish (in gram fresh weight) are presented as percentage of total fish biomass assessed by a combination of multi-mesh gill netting and hydroacoustic surveys. The high proportion of herbivorous fish is shown in black. The commercial fisheries is traditionally based on a few large-sized species. The main part of the existing biomass represents "untapped" resources" (acc. to Schiemer, 2008) 
A strong focus of the Fishstrat program was the detailed assessment of the socioeconomics of the riparian population, especially the role of fisheries and fish marketing for the rural development. An intensive interview program gave insight into the significance of the rural population's fisheries-related income but also into their critical livelihood situation close to the national poverty line.

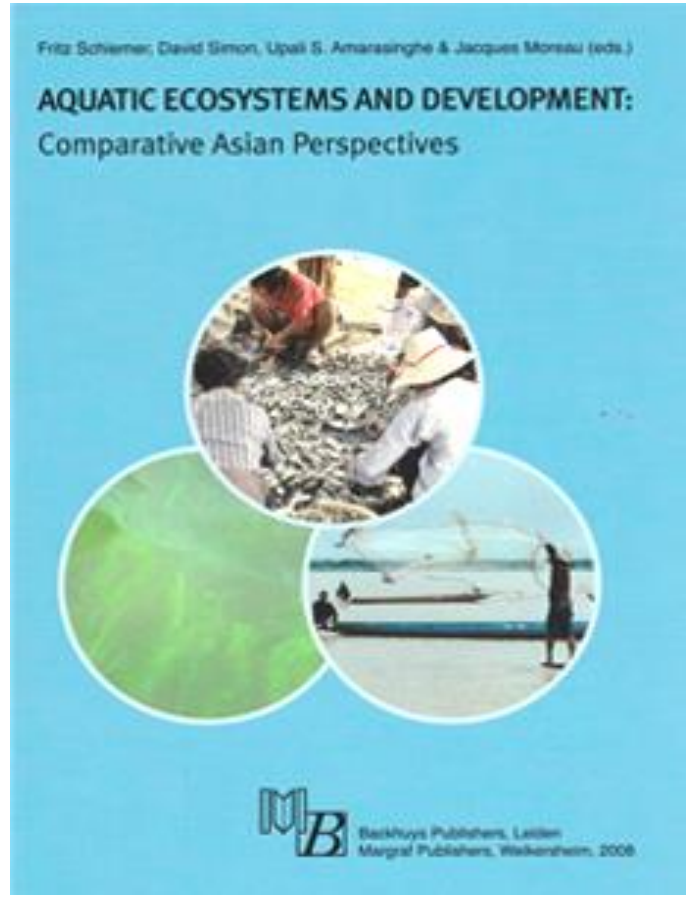

Figure 10. The results of the "Fishstrat" program with recommendations for sustainable management were published in a book on "Aquatic ecosystems and development: comparative Asian perspectives" (Schiemer et al. 2008)

The program was officially finished in 2003 , however it required several more years to analyze and integrate the results from more than forty scientists involved in the project. The major findings were published in a book on "Aquatic ecosystems and development: Comparative Asian perspectives" (Schiemer, Simon, Amarasinghe \& Moreau, ed. 2008) (Figure 10). The volume contains a number of summarizing papers on resource management.
The "Fishstrat" program, with its broad focus on limnology, fish ecology and socioeconomics of the riparian population, was a major step in learning with regard to the requirements for sustainable management. The project led to a combination of several scientific disciplines, although the teams carried out their work independently from each other. We moved in the right direction, however we did not accomplish the transdisciplinary step of a long-term interaction with practitioners and an immediate "real world" application.

\subsection{Danube restoration: a transdisciplinary approach for developing remediation concepts for large rivers}

An example of a more transdisciplinary nature refers to the conception of restoration programs at the Danube in Austria. It illustrates the advantage and potential of scientists becoming directly involved in a continued dialogue with stakeholders, authorities and decision makers.

My engagement started more than 30 years ago with the discussion surrounding the possible effects of a projected hydropower dam in the alluvial floodplains at Hainburg, downstream of Vienna. Scientists expressed warnings of the ecological consequences. After strong public intervention, the project was stopped and an "Ecology Commission" was tasked by the Austrian government to discuss options for future management of the river-floodplain system.

This discussion process, which continued over several years, involved authorities, stakeholders, engineers, hydrologists and ecologists. It led to a growing mutual understanding between the various parties and demonstrated the necessity for a more integrated, interdisciplinary approach of science and a transdisciplinary approach of all parties for the identification of problems and potential solutions. 


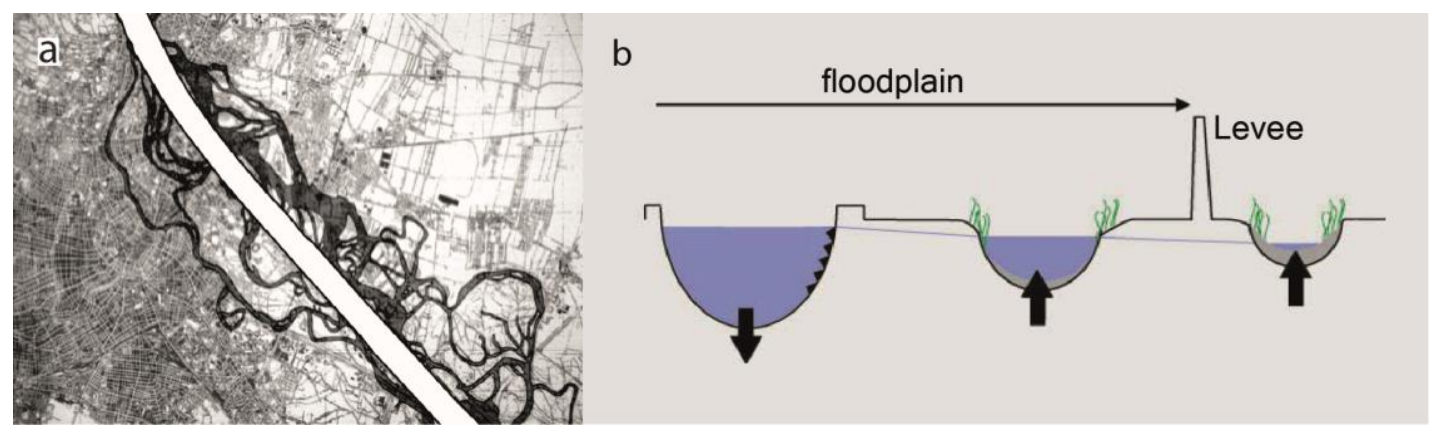

Figure 11. River regulation and damming have major impacts on the structure and function of river systems.

a) River regulation of the braided Danube at Vienna with extensive floodplains starting 1875. Engineering goals were the creation of a single channel with fortified embankments and a confined inundation area.

b) Schematic presentation of the main measures and the long-term trends initiated (arrows): the continued incision of the riverbed and the aggradation of the former side arms lead to a loss ecological integrity between river and floodplains (acc. to Schiemer et al. 1999).

Despite long-term consequences of river regulation and the effects of river damming in the upstream section, the "Ecology Commission" recognized the conservation value and the potential for restoring fluvial processes in the Danubian floodplains between Vienna and the Slovakian border.

A decision was therefore reached to conserve this river-floodplain section by creating an "Alluvial Zone National Park". All of the major rivers in the industrialized world have been changed by regulation and damming. The Danube, for example, has been strongly affected by regulation schemes starting in the second half of the 19 th century.

The channelization and limitation of flood events through lateral levees led to a continued trend of incision of the riverbed, causing an accelerating loss of connectivity between the river and its extensive floodplains (Figure 11). This led to ecological deficiencies and a growing request from various stakeholders for remediation measures (Buijse et al. 2005).

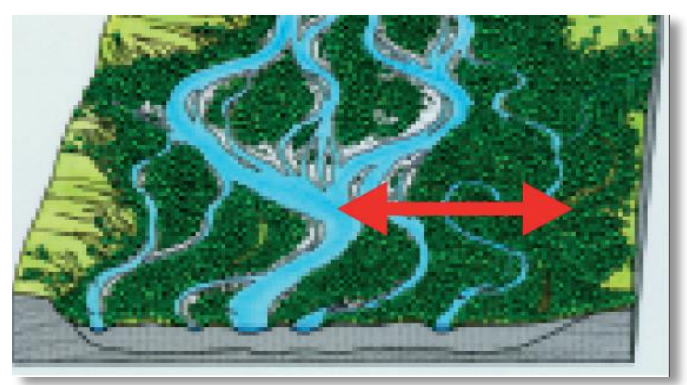

Figure 12. Rivers and their riparian zones provide significant ecological services (e.g. buffer capacity for floods, self purification processes, natural transport and storage, high biodiversity), which depend on the connectivity of the main channel with the floodplains.

Practical measures have to be based on a detailed understanding of the major drivers governing the interactive river-floodplain ecosystem (Figure 12). For river-floodplain systems, the key feature is the floodcontrolled geomorphological dynamics, which result in a characteristic habitat turnover rate of the riverine landscapes, their habitat composition and specific ecological functions and biota. To understand these interactions between fluvial processes and ecology, an interdisciplinary analytical approach is required. 
The apparent challenge is to follow the cause-effect chain between the governing factors hydrology and sediment load and the resulting landscape dynamics and ecology (Arthington et al. 2010, Naiman et al. 1988, Naiman et al. 2005, Zalewski 2000) (Figure 13). This approach allows diagnostic and prognostic tools regarding the effects of management measures on ecological processes (McClain et al. 2003, Decamps et al. 2004) and biodiversity (Ward et al. 1999) to be derived. Such an ecohydrological framework constitutes the basis for management (Poff et al. 2003, Surridge \& Harris 2007, Nilsson et al. 2007, Schiemer 2015).

Management faces the challenge to incorporate the interests of various stakeholders of different power and influence in the conception and implementation of a given program. For the floodplains downstream of Vienna, the interests in question are flood control, provision of drinking-water, navigation and conservation.

There is a high political priority for improving a Trans-European navigation network (PanEuropean Transport Corridor), for which the river section of the national park is considered a bottleneck. On the other hand, administration of the "Alluvial Zone National Park" is responsible for improving the ecological conditions, especially the integration of the floodplains with the river, and the natural dynamics of the inshore with its high ecological relevance for aquatic processes and habitat for characteristic biota.
It is apparent that navigation and conservation have contrary interests (Schiemer et al. 1999). In order to find a solution and bridge these diverging interests, an executive board consisting of administrators, planners, hydrologists, ecologists and major stakeholders was commissioned. The envisaged goal was to develop an "Integrated River Engineering Project", for the $50 \mathrm{~km}$ stretch from Vienna to the Austrian-Slovakian border, combining measures to improve both the navigation channel and the ecological conditions.

In the process to reach a compromise, it proved necessary to generate new planning concepts and technical means to achieve these goals. This planning of the possible alternatives had to be detailed enough to allow a benchmarking of their ecological consequences, especially with regard to the nature of the inshore structure and the lateral integration of the river and floodplain (Reckendorfer et al. 2005).

The effort to achieve a compromise and find a technical solution was a long and winding road. The discussion continued over nearly three years, during which the guiding role of science for the conception and evaluation of restoration plans became apparent. It proved imperative to involve scientific teams and provide them with a strong mandate in the search for sustainable management and restoration concepts for waterways.

The assignment was a major school of learning of transdiciplinary approaches and of the obstacles in the cooperation between scientists, engineers, stakeholders and authorities. Meanwhile several experimental

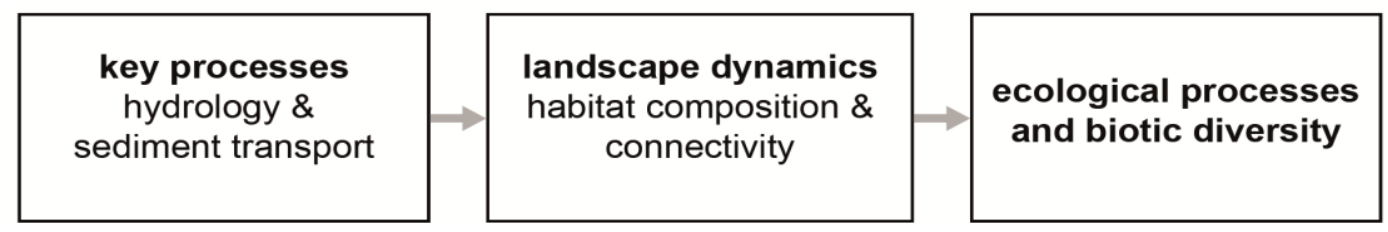

Figure 13. The main challenge for management and restoration of river-floodplain systems is to analyze the cause-effect chain between hydrology and sediment transport, the resulting landscape dynamics and, in turn, the ecological processes and biotic diversity 
steps of the program have been realized, but the political will for implementation of the whole engineering program is still pending.

\section{LEARNINGS AND RECOMMENDATIONS}

Combining these long-term experiences with different environmental scenarios, stakeholder interests and political frameworks, some overall conclusions can be formulated regarding integrated research scope and the necessity for science to get involved in a continued dialogue with practitioners. Science faces multiple challenges. In a recent paper based on research on water resource management in South-East Asia, we discussed these issues and illustrated the difficulties in a simple schematic graph (Figure 14) (Simon \& Schiemer 2015).

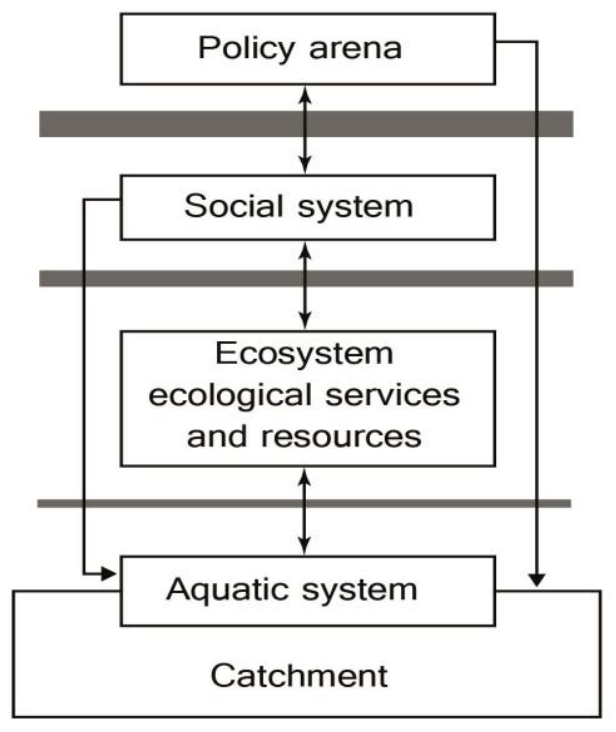

Figure 14. Scheme of major inter-relationships which are significant for formulating sustainable management concepts. The boxes identify the water body within its catchment as the resource base, its ecological services, the socio-economy of the riparian population, and the controlling authorities and decision makers. The horizontal bars define the barriers of increasing resistance, which have to be overcome (from Simon \& Schiemer, 2015).
The graph identifies the different aspects and compartments which have to be considered: the ecology of the water bodies within their catchment context, their ecosystem services, the associated socio-ecological system of the rural people and the policy arena where the rules for the utilization of the resource are defined. The vertical arrows show bottom-up and top-down influences. The horizontal bars indicate the barriers and degrees of resistance for an integrative scope and especially the challenge of achieving a transdisciplinary planning and decision process based on praxis-oriented research.

\subsection{The challenge for science: combining an analytical with a synoptic approach}

Sustainable management has to be based on a system understanding. The principal task is to define and identify key environmental factors governing the resource base, including human interactions and impacts.

It is necessary to assess the social forces and traditions of resource use in an analytical form and to derive predictive models to evaluate the possible impacts of management measures. For practical reasons, it is imperative to analyze the chain of causeeffect relationships of key influences. In a very simplified scheme, this is illustrated for the utilization of tropical reservoirs for fisheries.

The cause-effect chain is illustrated in a bottom-up form (Figure 15), starting with the regulation of the trophic state by the loading of nutrients from the catchment. This trophic state of a waterbody in turn determines the productivity of fisheries and consequently the protein supply for the riparian population.

In a similar way, the top-down effects have to be analyzed. This analytical scope is imperative. However, since we are dealing with complex interactions and networks of interrelationships, it is impossible in praxis to model all the interactions. Therefore it is 
necessary to maintain a synoptic view of the socio-ecological system as a whole.

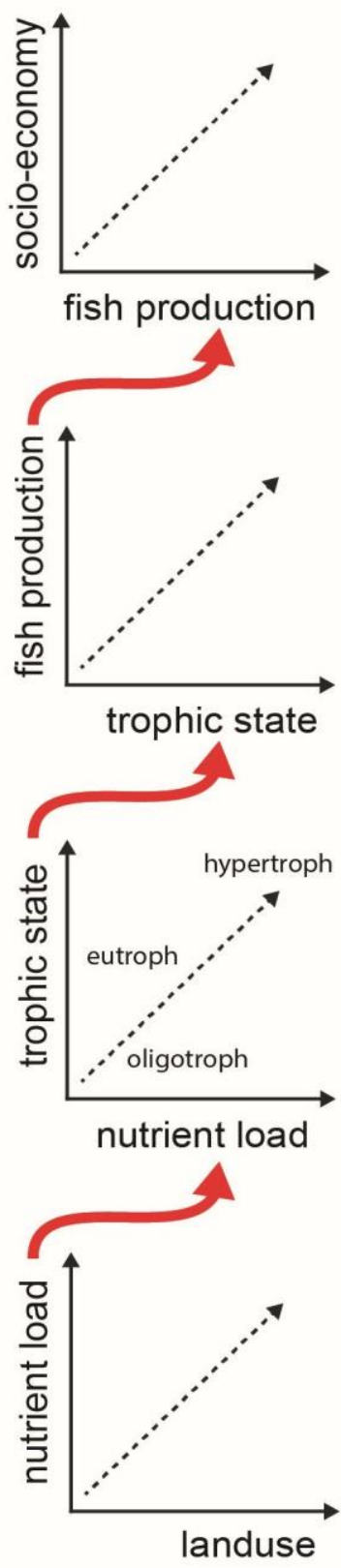

Figure 15. The analytical approach of science required in sustainable management is exemplified by the cause-effect chain to be adressed: catchment nutrient loading, trophic state of water-bodies, their fisheries potential, and finally its significance for the riparian population

\subsection{From multidisciplinarity to interdisciplinarity}

It slowly becomes apparent that a multidisciplinary research orientation, where the problem identification is carried out within the individual disciplines and the integration of research findings occur posthoc, is insufficient in order to gain a detailed understanding of the functioning of complex systems.

It has to be substituted by an interdisciplinary approach with a stronger conceptual integration of individual research fields leading to new science profiles e.g. ecologyhydrology or eco-sociology (Figure 16). This has to be achieved by joint problem identification and hypothesis building (Simon \& Schiemer 2015)

The practice shows that scientists commonly find it difficult to step beyond the "comfort zone" of their individual subject. Even among natural sciences, e.g. Hydrology and ecology, such barriers for the formulation of integrative research exist.

The challenges are even more formidable in bridging disciplines with a different epistemological structure, e.g. ecology and sociology. In order to overcome these intellectual barriers, academic curricula with an integrative scope have to be strengthened (Bruce et al. 2004).

A further challenge is the knowledge transfer to practitioners. The rapidly expanding field of translational research identifies ways that provide new knowledge and recommendations for practical application.

Despite the enormous growth of literature in this new research orientation, at present there is a lack of a common glossary, a focused communication platform and a shared research framework (Brandt et al. 2013). Further development in this direction requires incentives both from the social and environmental disciplines. 

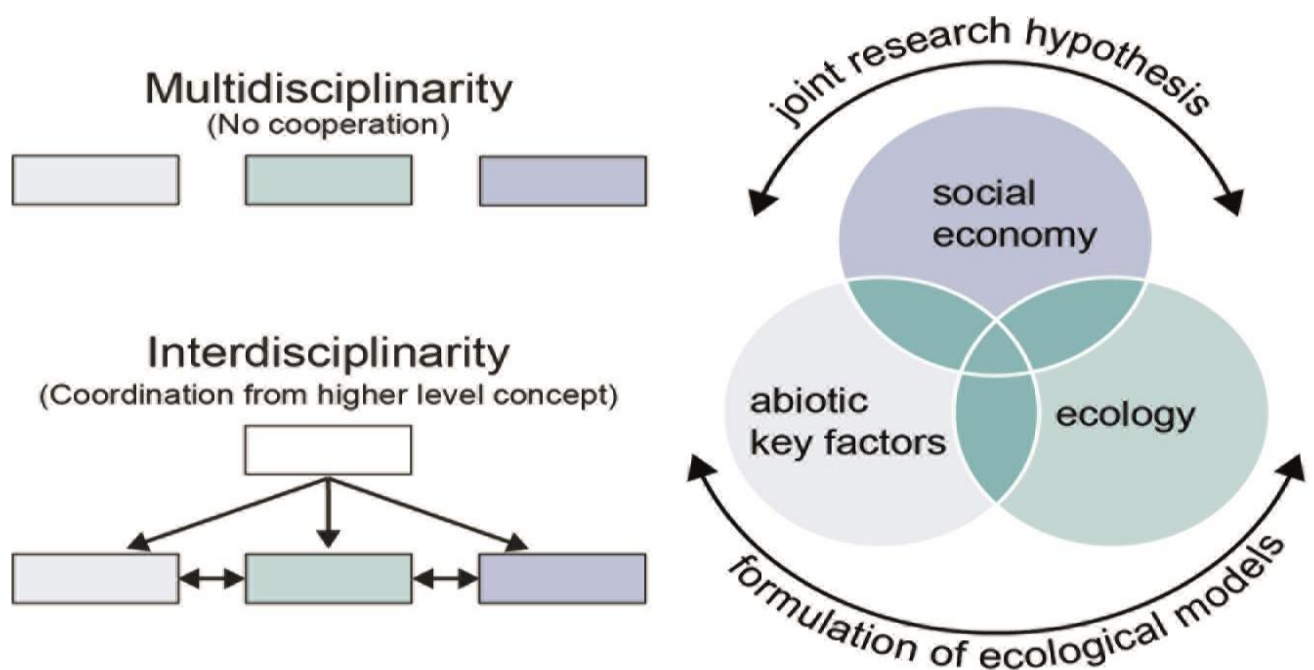

Figure 16. The left side graph identifies the meaning of multidisciplinarity vs. interdisciplinarity in science (acc. to Max-Neff, 2005). Right side: the process of integration and the formulation of joint hypothesis required to achieve interdisciplinarity.

\subsection{Policy arena: scientists should get involved in "real world" issues}

Although there is growing awareness that sustainable management requires a scientific foundation, in practice the acceptance and utilization of research findings for management is a slow process. Decisions are rarely based on evidence-based information but are traditionally controlled by stakeholder interests of different socio-economic standing and political influence. Controversies between the various interests often delay urgent practical measures. We experience this continuously in issues of global scale.

From the point of view of science, this means that pure academic work is not sufficient. In order to be effective, a more direct involvement with stakeholders and decision makers is necessary. Acceptance of scientific knowledge is increased through direct engagement and a continued sciencepractitioners dialogue (Max-Neef 2005, Lawton 2007, Likens 2010). However, there is often resistance by authorities and decision makers to involve independent expert panels for fear of loss of control and influence. On the other side, there is also hesitation in part of the scientific community to become involved in real-world problems, because applied science is often considered academically less rewarding.

This definitely is a misguided attitude: a direct involvement in management-oriented research stimulates new and significant avenues of science. It offers science the advantage of readily applying "real world" framework conditions in its research programs and model building.

Scientists should take a manifold and guiding role in the formulation of sustainable management concepts. Their role lies in identifying problems and hazards, and defining procedures and pathways for finding acceptable compromises and comprehensive solutions. The implementation of management programs has to be carried out in a step-wise, adaptive form, accompanied by a research-oriented monitoring to assess the impacts of measures and - if necessary make corrections and improvements. In this form, the development of sustainable management can be seen as a large-scale experiment at the eco-social system level. 
The involvement of scientists can range from consultation to participation in advisory expert panels, or to being part of comanagement boards with executive power. The adequate structures and forms of involvement of science depend on the geographic scale - national, regional or local - the nature of the environmental systems and the order and dimensions of problems which have to be addressed (Figure 17). Larger, more complex systems raise higher difficulties, due to larger numbers of stakeholders, greater socio-ecological diversity and more complex linkages.

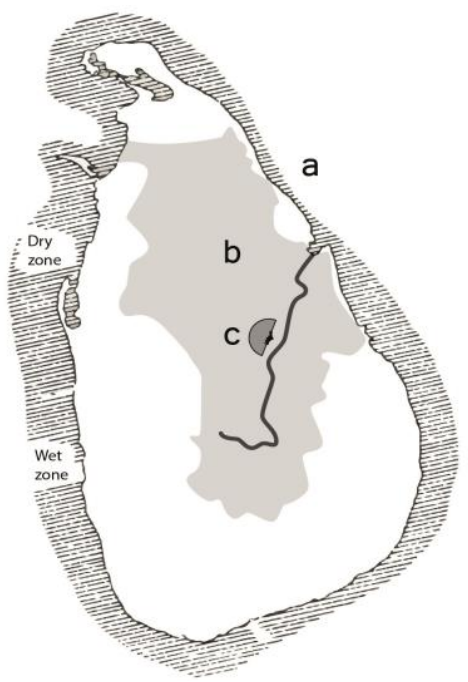

Figure 17. Different geographic scales require different forms of involvement of scientist in management conception, illustrated on the example of Sri Lanka.

a) national scale, the whole country, b) regional scale, Mahaweli Development program, c) local scale, Parakrama Samudra reservoir and its vicinity. At the national level, expert panels bridging the interests of different ministries are required. At the local level co-management boards should be involved.

The selection of expert panels - if they are of an advisory nature or involved in comanagement arrangements - has to be based on a set of well-defined criteria. Members selected should have a high scientific profile, a proven ability for interdisciplinary research and willingness to be involved in transdisciplinary approaches. Expert panels should be independent and not interfered with by short-term political interests. They should have clearly identified goals, a rigid time structure, well-defined responsibilities and long-term mandates. Their recommendations should be made public.

Especially in countries with small research communities like in Austria or Sri Lanka, it is advisable to seek international support and advice in structuring such expert panels and identifying the candidates.

Taking the water issues of Sri Lanka as an example, there are many demands for a bridging approach in problem identification and assessment, which go far beyond the responsibility of individual ministries or governmental institutions. The hydrological control for hydropower generation and irrigation, for example, has major effects on the fisheries- potential of the reservoirs and the water quality of the aquatic network including the groundwater table.

The issue of water quality and the identification of hazardous and toxic substances leading to health problems, e.g. the chronic kidney disease (Noble et al. 2014), require an integrated view on the land-use of the catchment, the socioeconomic conditions, the agricultural practices, the hydrological regulations etc.

In order to achieve such an integrated view, a wide range of research fields - from meteorology, limnology, soil geochemistry to health sciences and socio-ecology - has to be involved in an interdisciplinary form. Independent expert panels on integrated aquatic resource management should be installed in order to define the bridging aspects of water issues beyond the scope of individual ministries.

They have to make use of the information provided by governmental research institutions and help to direct their research 
scope, orientation and priorities. Their task should be supported by a nation-wide water quality assessment scheme covering biological, chemical and toxicological parameters with a strongly improved capacity and quality control.

In summing up, we can formulate recommendations for science involvement and operational procedures in the development of sustainable management plans. The focus has to be on the promotion of comprehensive concepts, taking into account all concerned parties and assuring their active involvement. The main challenge is to achieve a continued dialogue between stakeholders, authorities, decision makers and scientists.

The primary task for science is to develop an integrative system-oriented understanding with predictive power and to provide this knowledge to the practitioners in appropriate form. The cooperation with practitioners ranges from being part of advisory panels to being engaged in executive co-management boards. A stronger and longer-term involvement improves the chances both for an advancement of science as well as of management skills to achieve sustainable solutions.

Management programs should be implemented in an adaptive form, i.e. guided by science-based monitoring programs to assess successes and failures and increase our knowledge base by learning on the way. The participation of science requires well-defined institutional frameworks with long-term mandates and clearly defined responsibilities. Our experiences point to the necessity to strengthen institutional and legal frameworks, which guarantee a scientific approach for holistic planning and transdisciplinary decision processes.

\section{ACKNOWLEDGEMENT}

I would like to thank Prof. Swarna Piyasiri for the invitation to present a key-note lecture at the "International Conference on Multidisciplinary Approaches" (iCMA 2015) held in Colombo in September 2015. During my visit Prof. Ivan Silva arranged meetings with colleagues at the Univ. of Jaffna and the Univ. of Ruhuna. These visits together with him and his son Nishchitha provided a good opportunity for discussions on aquatic resource management in Sri Lanka.

I wish to thank Dr. Amara Gunatilaka for critically commenting on the manuscript, Mag. Benjamin Seaman for correcting the language and Mrs. Michaela Punz for help in the preparation of the figures.

\section{REFERENCES}

AMARASINGHE US, DUNCAN A, MOREAU J, SCHIEMER F, SIMON D \& VIJVERBERG J. Promotion of sustainable capture fisheries and aquaculture in Asian reservoirs and lakes. - Hydrobiologia. 2001; 458: 181-190.

ARTHINGTON AH, NAIMAN RJ, MCCLAIN ME \& NILSSON C. Preserving the biodiversity and ecological services of rivers: new challenges and research opportunities. - Freshwater Biology. 2010; 55: 1-16.

BENNETT EM, PETERSON GD \& GORDON LJ. Understanding relationships among multiple ecosystems. - Ecological Letters. 2009; 12: 1394-1404.

BOGARDI JJ, DUDGEON D, LAWFORD R, FLINKERBUSCH E, MEYN A, PAHLWOSTL C, VIELHAUER K \& VÖRÖSMARTY C. Water scarcity for a planet under pressure: interconnected challenges of a changing world call for 
sustainable solutions. - Current Opinion in Environmental Sustainability. 2012; 4: 35-43.

BRAND P, ERNST A, GRALLA F, LUEDERITZ C, LANG DJ, NEWIG J, REINERT F, ABSON DJ \& VON WEHRDEN H. A review of transdisciplinary research in sustainability science. - Ecological Economics. 2013; 92: 1-15.

BRUCE A, LYALL C, TAIT J \& WILLIAMS R. Interdisciplinary integration in Europe: the case of the fifth framework programme. - Futures. 2004; 36: 457-470.

BUIJSE AD, KLIJN F, LEUVEN RSEW, MIDDELKOOP H, SCHIEMER F, THORP JH \& WOLFERT HP. Rehabilitation of large rivers: references, achievements and integration into river management. - Arch. Hydrobiol. 2005; Suppl. 115 (Large Rivers. 15): 715-738.

DAILY GC, ALEXANDER S, EHRLICH PR \& GOULDER L. Ecosystem services: benefits supplied to human societies by natural ecosystems. - Ecological Society of America. 1997.

DECAMPS H, PINAY G, NAIMAN RJ, PETTS GE, MCCLAIN ME, HILLBRICHTILKOWSKA A, HANLEY TA, HOLMES RM, QUINN J, GIBERT J, PLANTY TABACCHI A-M, SCHIEMER F, TABACCHI E \& ZALEWSKI M. Riparian zones: where biogeochemistry meets biodiversity in management practice. - Pol. J. Ecol. 2004; 52: 3-18.

DE SILVA SS \& SIRISENA HKG. New fish resources of reservoirs in Sri Lanka: feasibility of introduction of as subsidiary gillnet fishery for minor cyprinids. -Fisheries Research. 1987; 6:17-34.

DUNCAN A, GUNATILAKA A \& SCHIEMER F. Limnological Aspects of Landscape Managment in Sri Lanka. - In: ERDELEN, W., PREU, C., ISHWARAN, N., MADDUMA BANDARA, C. M. (eds.): Ecology and Landscape Management in Sri
Lanka. Conflict or Compromise? Proceedings of the international and Interdisciplinary Symposium "Ecology and Landscape Management in Sri Lanka", Margraf Scientific Books. 1993; 381-395.

DUNCAN A \& SCHIEMER F. Fish pressures on ecosystems: dynamic, holistic indices. - In: DE SILVA, S.S. (ed.): Reservoir fishery management and development in Asia. Proceedings series. International Development Research Centre. Ottawa. 1988; 176-194.

GUNATILAKA A. Phosphorous and phosphatase dynamics in a tropical manmade lake based on diurnal observations.In: SCHIEMER, F. (ed.) Limnology of Parakrama Samudra - Sri Lanka - a case study of an ancient man-made lake in the tropics. Developments of Hydrobiology. 1983; 12: $35-47$.

KORSGAARD L \& SCHOU JS. Economic valuation of aquatic ecosystem services in developing countries. - Water Policy. 2010; 12: $20-31$.

LAWTON JH. Ecology, politics and policy. - Journal of Applied Ecology. 2007; 44: 465-474.

LE CREN ED \& LOWE-McCONNELL RH. (eds.) The functioning of freshwater ecosystems. Cambridge University Press. 1975.

LIKENS GE. The role of science in decision making: does evidence-based science drive environmental policy? Frontiers in Ecology and the Environment. 2010; 8: 1-9.

MAX-NEEF MA. Foundations of transdisciplinarity. - Ecological Economics. 2005; 53: 5-16.

MCCLAIN ME, BOYER EW, DENT CL, GERGEL SE, GRIMM NB, GROFFMAN 
PM, HART SC, HARVEY JW, JOHNSTON CA, MAYORGA E, McDOWELL WH \& PINAY G. Biogeochemical hot spots and hot moments at the interface of terrestrial and aquatic ecosystems. - Ecosystems. 2003; 6: 301312.

NAIMAN RJ, DECAMPS H \& McCLAIN ME. Riparia: ecology, conservation and management of streamside communities. Elsevier. 2005.

NAIMAN RJ, DECAMPS H, PASTOR J \& JOHNSTON CA. The potential importance of boundaries to fluvial ecosystems. - J. North Am. Benthol. Soc. 1988; 7: 289-306.

NILSSON C, JANSSON R, MALMQVIST $B$ \& NAIMAN RJ. Restoring riverine landscapes: the challenge of identifying priorities, reference states and techniques. Ecology and Society. 2007; 12: 1-6.

NOBLE A, AMERASINGHE P, MANTHRITHILAKE H \& ARASALINGAM S. Review of literature on chronic kidney disease of unknown etiology (CKDu) in Sri Lanka. - Colombo, Sri Lanka: International. Water Management Institute (IWMI). (IWMI Working Paper 158). 2014. doi: 10.5337/2014.206.

POFF NL, ALLAN JD, PALMER MA, HART DD, RICHTER BD, ARTHINGTON AH, ROGERS KH, MEYER JL \& STANFORD JA. River flows and water wars: emerging science for environmental decision making. - Front. Ecol. Environ. 2003; 1: 298-306.

RECKENDORFER W, SCHMALFUSS R, BAUMGARTNER C, HABERSACK $\mathrm{H}$, HOHENSINNER S, JUNGWIRTH M \& SCHIEMER F. The Integrated River Engineering Project for the free-flowing Danube in the Austrian Alluvial Zone National Park: contradictory goals and mutual solutions. - Arch. Hydrobiol. 2005; Suppl. 115 (Large Rivers. 15): 613-630.

SCHIEMER F. Parakrama Samudra Limnology Project - an interim review. Verh. Internat. Verein. Limnol. 1981; 21: 993-999.

SCHIEMER F. (ed.) Limnology of Parakrama Samudra, Sri Lanka: a case study of an ancient man-made lake in the tropics. Developments in Hydrobiology 12, Junk Publishers. 1983.

SCHIEMER F. Significance of filter-feeding fish in tropical freshwaters. - In: SCHIEMER F \& BOLAND KT. (eds.): Perspectives in Tropical Limnology. SBP Academic Publishing. 1996; 65-76.

SCHIEMER F. The limnological basis for aquatic resource management of tropical reservoirs and lakes. - In: SCHIEMER, F., SIMON, D., AMARASINGHE., US, MOREAU, J. (eds.): Aquatic ecosystems and development: comparative Asian perspectives. Backhuys and Margraf. 2008; 435-466.

SCHIEMER F. Building an eco-hydrological framework for the management of large river systems. - Ecohydrology \& Hydrobiology. 2015.

SCHIEMER F, AMARASINGHE US, FROUZOVA J, SRICHAROENDHAM B \& SILVA EIL. Ecosystem Structure and Dynamics - A management basis for Asian reservoirs and lakes. - In: DE SILVA, S.S. (ed.). Reservoir and culture-based fisheries: biology and management. ACIAR Proceedings No. 98: 2001;215-226.

SCHIEMER F, BAUMGARTNER C \& TOCKNER K. Restoration of floodplain rivers: the "Danube restoration project". Regul. Rivers: Res. Mgmt. 1999; 15: 211244. 
SCHIEMER $F$ \& DUNCAN A. The Parakrama Samudra Limnology Project a summary of main results. - In: SCHIEMER, F. (ed.): Limnology of Parakrama Samudra, Sri Lanka: a case study of an ancient manmade lake in the tropics. Developments in Hydrobiology. 1983; 12: 201209.

SCHIEMER $F$ \& DUNCAN A. The significance of the ecosys $\neg$ tem approach for reservoir management. - In: DE SILVA SS. (ed.): Reservoir fishery management and development in Asia. Proceedings series, International Development Research Centre. Ottawa. 1988; 183-194.

SCHIEMER F, SIMON D. Aquatic resource management in tropical Asia: Developing a transdisciplinary approach for sustainable development. - In: SCHIEMER, F., SIMON, D., AMARASINGHE., US, MOREAU, J. (eds.): Aquatic ecosystems and development: comparative Asian perspectives. Backhuys and Margraf. 2008; 467-501.

SCHIEMER F, SIMON D, AMARASINGHE US \& MOREAU J. (eds.) Aquatic ecosystems and development: comparative Asian perspectives. Backhuys and Margraf. 2008.

SILVA IEL \& SCHIEMER F. Regulation of phytoplankton primary production in Sri Lankan reservoirs. - In: SCHIEMER F, SIMON D, AMARASINGHE US \& MOREAU J. (eds.): Aquatic ecosystems and development: comparative Asian perspectives. Backhuys and Margraf. 2008; 121-134.

SIMON D \& SCHIEMER F. Crossing boundaries, complex systems, transdisciplinarity and applied system agendas. - Current Opinion in Environmental Sustainability. 2015; 12: 6-11.

SURRIDGE B \& HARRIS B. Science-driven integrated river basin management: a mirage? - Int. Science Rev. 2013; 32: 298-312.
WARD JV, TOCKNER K \& SCHIEMER F. Biodiversity of floodplain river ecosystems: ecotones and connectivity. - Regul. Rivers: Res. Mgmt. 1999; 15: 125-139.

ZALEWSKI M. Ecohydrology - the scientific background to use ecosystem properties as management tools toward sustainability of water resources. - Ecol. Engineering. 2000; 16: 1-8. 